\title{
The performance of Amaranthus cruentus and Celosia argentea as affected by varying sowing depths
}

\author{
F.O. Odeleye ${ }^{1^{*}}$ and A. O. Olufolaji ${ }^{2}$ \\ ${ }^{1}$ Dept. of Crop Protection and Environmental Biology, University of Ibadan, Nigeria. \\ ${ }^{2}$ National Horticultural Research Institute, Jericho, Idi-ishin, Ibadan,Nigeria \\ *Corresponding author: gbengaodeleye2@yahoo.com \\ ABSTRACT
}

\begin{abstract}
Screen house trials were carried out to evaluate the optimum sowing depths of Amaranthus and Celosia at the National Horticultural Research Institute, Ibadan, Nigeria. Seeds of NHAc3 and ED82/1040A varieties of Amaranthus and local green and TLV8 of Celosia (chosen on the basis of maturity period) were sown at 0,1,2 and $3 \mathrm{~cm}$ depths using split-split design in randomized blocks with 4 replications. Data were taken on \% germination, seedling emergence and establishment indices. Results indicate that Celosia had a higher \% seedling emergence than Amaranthus . However, Amaranthus grew significantly taller than Celosia at plant establishment. Highest number of seedlings emerged at $0 \mathrm{~cm}$ depth but plants had highest number of leaves and total fresh vegetable production at $1 \mathrm{~cm}$ sowing depth. The two crops sown at and $1 \mathrm{~cm}$ gave significantly higher root development index than other interactive effects. However, the highest shoot development index was obtained at $0 \mathrm{~cm}$ depth. The study demonstrated a significant interaction of sowing depth $\mathrm{x}$ variety such that the varieties (irrespective of species) performed best at $1 \mathrm{~cm}$ depth. The early maturing variety in the crops also had higher vigour, germination and root and shoot development indices than the late maturing variety.
\end{abstract}

Keywords: Sowing depth, shoot/root development indices, seedling emergence, Amaranthus, Celosia

\section{INTRODUCTION}

Amaranthus cruentus and Celosia argentea are two leafy vegetable crops with wide acceptance in Nigeria and worldwide. They provide cheap sources of vitamins minerals and proteins. The leaves are consumed as vegetable whereas the seeds could be processed into snacks. The productivity of these crops is largely dependent on the cultural practices employed during their cultivation. Some of the cultural practices employed during the cultivation of these crops in Nigeria include intercropping with other crops like maize (Muoneke and Ndukwe, 2008; Awe and Abegunrin, 2009); fertilizer application (Zobolo,et al, 2008); weeding Ogunyemi et al., 2001 ), disease and pest control (Lovisolo and Lisa,1979, Siddiqui and Alam, 1989) and depth of sowing

Seedling emergence and establishment has been shown to be a function of size of the seed and the depth of sowing during cultivation. Emergence is an expression of a complex interaction of seed factors including genotype, vigour, and soil factors acting at or after the time of sowing. For example, evidence showed the superiority of large carrot seeds over small ones in emergence and standard establishment (Jacobsohn and Globerson, 1980). Seedling emergence is also influenced by the depth of sowing as small seeded crops like amaranths have limited food reserves to support germination and seedling emergence (Mayer and Polkajoff-Mayber, 1975). This limitation often restricts the depth from which an amaranth seedling could emerge. Webb, et al., (1987) reported that seeding as deep as $2.5 \mathrm{~cm}$ should be practical in friable soils if seeding rates are adjusted to compensate for reduced percent emergence associated with depth of sowing. Mayer and Polkajoff-Mayber (1975) also reported that emergence could be influenced by soil type since soil, strength has an important type of effect on the ability of roots to penetrate into the soil especially through clods or firmly structured layers. The rootlet must therefore develop a pressure to pierce the soil. The growing roots could develop a pressure up to 10 bars.

Depth of sowing is a cultural practice that may be particularly crucial for Amaranthus and Celosia since they have very small seeds. In okra with relatively large seeds, Odeleye et al reported that planting beyond $3 \mathrm{~cm}$ depth led to reduced emergence, vigour and yield. Effects of sowing depths have also been reported in pigeon pea (Tayo, 1983); Corn (Gupta et 
al 1983, Alessi and Power (1971), Soybean, Abrecht 1989 , but the seeds of all these crops are much bigger than those of Amaranthus and Celosia. Farmers usually mix the seeds of these crops with soil and broadcast. This practice usually expose the seeds on the soil surface. This may adversely affect the germination and performance of these crops. It is pertinent therefore to determine the optimum sowing depth for Amaranthus and Celosia which was the objective of this study.

\section{MATERIALS AND METHODS}

Two trials were carried out to evaluate the optimum depth of sowing of Amaranthus and Celosia at the greenhouse of National Horticultural Research Institute, Ibadan. Seeds of $\mathrm{NHA}_{c} 3$ and ED82/1040A varieties of Amaranthus and local green and TLV8 of Celosia were sown at $0,1,2$, and $3 \mathrm{~cm}$ depths. One hundred seeds were sown per depth per variety in 60 $x 18 \times 6 \mathrm{~cm}$ nursery trays.

The planting medium was top soil mixed with cured poultry droppings in the ratio 4:1. Records were taken of the number of germinated seedlings for depth 0 and emerged seedlings for 1,2 and $3 \mathrm{~cm}$ depths of sowing up till 2 weeks and the percent seedling establishment at 4 weeks.

The experiment involved two varieties of Amaranthus $\left(\mathrm{NHA}_{C} 3\right)$ and ED82/1040A) and two varieties of Celosia (TLV8 and Local green). The design was split plot in randomized complete block design with 4 replicates.

\section{RESULTS}

The percent seedling emergence was significantly higher in Celosia than in Amaranthus. At plant establishment (4 weeks after sowing) Amaranthus grew significantly taller than Celosia. Among the sowing depth, seedling emergence was significantly different in the order $0 \mathrm{~cm}>1 \mathrm{~cm}>2 \mathrm{~cm}>3 \mathrm{~cm}$; while the significant difference in the leaf area was in the order $1 \mathrm{~cm}>0 \mathrm{~cm}, 2 \mathrm{~cm}>\mathrm{cm}$. the highest leaf area production was recorded in Celosia sown at $1 \mathrm{~cm}$ depth, while the least occurred in Amaranthus sown at $3 \mathrm{~cm}$ depth (Table 1).

Table 1: Mean values of the vegetable characters of $A$. cruentus and $C$. argentea at varying depths of sowing

\begin{tabular}{|c|c|c|c|c|}
\hline Treatment & Emergence & $\begin{array}{l}\text { Stem height }\left(\mathrm{cm}^{2}\right. \\
\text { plant }^{-1}\end{array}$ & Leaf number & Leaf area $\left(\mathrm{cm}^{2}\right.$ plant $^{-1}$ \\
\hline Celosia & $52: 19$ & 7.45 & 7.58 & 64.02 \\
\hline Amaranthus & 42.19 & 9.78 & 7.76 & 25.55 \\
\hline $\operatorname{LSD}(P=0.05)$ & 6.89 & 1.17 & 0.88 & 7.92 \\
\hline \multicolumn{5}{|l|}{ Depth } \\
\hline $0 \mathrm{~cm}$ & 61.56 & 8.43 & 7.45 & 30.94 \\
\hline $1 \mathrm{~cm}$ & 53.75 & 8.92 & 8.12 & 42.05 \\
\hline $2 \mathrm{~cm}$ & 42.50 & 9.20 & 8.30 & 26.67 \\
\hline $3 \mathrm{~cm}$ & 30.94 & 7.91 & 6.84 & 19.00 \\
\hline LSD (P=0.05) & 5.66 & 1.11 & 0.80 & 5.69 \\
\hline \multicolumn{5}{|l|}{ Depth $x$ spp } \\
\hline 0cm x Celosia & 80.63 & 7.78 & 7.84 & 35.16 \\
\hline $1 \mathrm{~cm} \times$ Celosia & 50.63 & 7.29 & 7.64 & 48.19 \\
\hline $2 \mathrm{~cm} \times$ Celosia & 45.63 & 7.63 & 7.99 & 30.32 \\
\hline $3 \mathrm{~cm} \times$ Celosia & 31.88 & 7.08 & 6.85 & 22.42 \\
\hline 0cm $\times$ Amaranthus & 42.50 & 9.09 & 7.06 & 26.72 \\
\hline $1 \mathrm{~cm} \times$ Amaranthus & 56.88 & 10.55 & 8.60 & 36.85 \\
\hline $2 \mathrm{~cm} \times$ Amaranthus & 39.38 & 10.77 & 8.61 & 23.03 \\
\hline $3 \mathrm{~cm} \times$ Amaranthus & 30.00 & 8.73 & 6.83 & 15.59 \\
\hline LSD $(P=0.05)$ & 9.54 & 1.76 & 1.29 & 10.30 \\
\hline
\end{tabular}

The total plant fresh weight was similar in both Amaranthus and Celosia species, however total vegetable production was higher at $1 \mathrm{~cm}$ depth than at the other three sowing depths which had similar values. Both species sown at $1 \mathrm{~cm}$ and $3 \mathrm{~cm}$ gave the highest and lowest total fresh vegetable production, respectively Table 2 .

The shoot development index which is an absolute figure and defined as the ratio of the dry matter accumulated in the shoot to the weight of viable seeds sown was significantly better in Celosia than in Amaranthus. The shoot development index was significantly different among the depths in the order $0 \mathrm{~cm}>1 \mathrm{~cm}>2 \mathrm{~cm}>3 \mathrm{~cm}$. the highest shoot development index was similar in both species and was similar but significantly lower in 1,2 and $3 \mathrm{~cm}$ depths of sowing than in $0 \mathrm{~cm}$ depth. Celosia at $0 \mathrm{~cm}$, Amaranthus at 0 and $1 \mathrm{~cm}$ gave significantly higher 
root development index than at the other interactive effects (Table 2).

Amaranthus cruentus: In this crop the \% seedling emergence was significantly higher in the early flowering $\mathrm{NHA}_{\mathrm{C}} 3$ than the late flowering ED82/1040A (Table 3). The percent seedling emergence was significantly different in the order $1 \mathrm{~cm}>2 \mathrm{~cm}>0 \mathrm{~cm}>$ $3 \mathrm{~cm}$. The variety $x$ depth interaction indicated that the highest seedling emergence occurred in $\mathrm{NHA}_{\mathrm{C}} 3$ sown at $1 \mathrm{~cm}$, while the least emergence was observed in ED82/10440A sown at 3cm depth (Table 3 ). The stem height per plant was similar in the two varieties while sowing at $1 \mathrm{~cm}$ and $2 \mathrm{~cm}$ depths gave similar but significantly taller plants than sowing at $0 \mathrm{~cm}$, and $3 \mathrm{~cm}$ depths both of which gave similar stem heights (Table 3 ).

Variety $\mathrm{NHA}_{C} 3$ at $1 \mathrm{~cm}$ and ED82/1040A at $1 \mathrm{~cm}$ and $2 \mathrm{~cm}$ depths gave significantly taller plants than all the other varieties $x$ sowing depth combinations. The highest number of leaves were produced at sowing depths $2 \mathrm{~cm}$ and $3 \mathrm{~cm}$, leaf area was in the order $1 \mathrm{~cm}$ $>2 \mathrm{~cm}$. $0 \mathrm{~cm}>3 \mathrm{~cm}$. Interaction showed that $\mathrm{NHA}_{C}$ and ED82/1040A at $1 \mathrm{~cm}$ depth were superior in leaf area production to all the other variety $x$ sowing depth interactions (able 3). The total plant fresh weight was similar in both varieties of Amaranthus but significantly different among the depth in the order $1 \mathrm{~cm}>2 \mathrm{~cm}>0 \mathrm{~cm}>3 \mathrm{~cm}$. At 4 week ED82/1040A at $1 \mathrm{~cm}$ depth gave the highest fresh vegetable production than all other variety $x$ effects (Table 4 ). The shoot development index was highest at $1 \mathrm{~cm}$ sowing depth and least at $0 \mathrm{~cm}$ (surface) and $3 \mathrm{~cm}$ sowing depths. Variety ED82/1040A gave the highest shoot development index when sown at $1 \mathrm{~cm}$ and the least at $3 \mathrm{~cm}$ (Table 4). The root development index was highest at $1 \mathrm{~cm}$ and least at $3 \mathrm{~cm}$ depth (Table 4).

Table 2: $\quad$ Mean values of total weight, shoot and root development indices of $A$. cruentus and $C$. argentea at varying depths of sowing depths

\begin{tabular}{|l|l|l|l|}
\hline Treatment & Total fresh wt. (g plant ${ }^{-1}$ ) & Shoot dev. Index $\mathbf{~ g g ~}^{-1}$ ) & Root dev. Index $\mathbf{~ g g ~}^{-1}$ ) \\
\hline Celosia & 1.38 & 4.05 & 0.252 \\
Amaranthus & 1.77 & 1.92 & 0.232 \\
LSD (P=0.05) & 1.83 & 0.53 & 0.098 \\
\hline Depth & & & \\
Ocm & 3.31 & 4.10 & 0.328 \\
1cm & 1.10 & 3.22 & 0.246 \\
2cm & 0.76 & 2.49 & 0.175 \\
3cm & 1.67 & 2.11 & 0.219 \\
LSD (P=0.05) & 0.79 & 0.41 & 0.074 \\
\hline Depth x spp & & & \\
Ocm x Celosia & 1.29 & 3.11 & 0.366 \\
1cm x Celosia & 2.19 & 2.99 & 0.208 \\
2cm x Celosia & 1.12 & 2.77 & 0.175 \\
3cm x Celosia & 0.92 & 1.09 & 0.258 \\
\hline Ocm x Amaranthus & 0.93 & 3.14 & 0.289 \\
1cm x Amaranthus & 4.44 & 1.99 & 0.284 \\
2cm x Amaranthus & 1.06 & 1.45 & 0.175 \\
3cm x Amaranthus & 0.61 & 0.71 & 0.181 \\
LSD (P=0.05) & 2.68 & & 0.130 \\
\hline
\end{tabular}


Table 3: Mean values of some vegetable characters of $A$. cruentus at varying depths of sowing

\begin{tabular}{|c|c|c|c|c|}
\hline Treatment & Emergence (\%) & $\begin{array}{l}\text { Stem height }\left(\mathrm{cm}^{2}\right. \\
\text { plant }^{-1}\end{array}$ & $\begin{array}{l}\text { Leaf number } \mathrm{cm}^{2} \\
\text { plant }^{-1}\end{array}$ & $\begin{array}{l}\text { Leaf area }\left(\mathrm{cm}^{2}\right. \\
\text { plant }^{-1}\end{array}$ \\
\hline $\begin{array}{l}\mathrm{NHA}_{\mathrm{C}} 3 \\
\text { ED82/1040A } \\
\text { LSD }(\mathrm{P}=0.05) \\
\text { Depth } \\
0 \mathrm{~cm} \\
1 \mathrm{~cm} \\
2 \mathrm{~cm} \\
3 \mathrm{~cm}\end{array}$ & $\begin{array}{l}51.7 \\
44.7 \\
4.75 \\
\\
40.8 \\
75.1 \\
48.8 \\
4.30\end{array}$ & $\begin{array}{l}9.7 \\
9.4 \\
1.10 \\
\\
8.4 \\
10.4 \\
10.8 \\
85\end{array}$ & $\begin{array}{l}12.2 \\
7.6 \\
7.64 \\
\\
7.6 \\
7.6 \\
9.0 \\
15.4\end{array}$ & $\begin{array}{l}25.2 \\
21.2 \\
4.61 \\
23.7 \\
32.5 \\
23.3 \\
14.6\end{array}$ \\
\hline $\begin{array}{l}\text { LSD (P=0.05) } \\
\text { Depth } \times \text { spp } \\
0 \mathrm{~cm} \times \text { NHAc3 } \\
1 \mathrm{~cm} \times \text { NHAc3 } \\
2 \mathrm{~cm} \times \text { NHAc3 } \\
3 \mathrm{~cm} \times \text { NHAc3 }\end{array}$ & $\begin{array}{l}4.30 \\
\\
40.5 \\
81.0 \\
55.5 \\
29.6\end{array}$ & $\begin{array}{l}1.37 \\
9.2 \\
10.7 \\
9.6 \\
9.1\end{array}$ & $\begin{array}{l}6.92 \\
7.5 \\
7.1 \\
9.9 \\
9.4\end{array}$ & $\begin{array}{l}3.22 \\
\\
26.3 \\
33.4 \\
24.8 \\
16.5\end{array}$ \\
\hline $\begin{array}{l}0 \mathrm{~cm} \times E D 82 / 1040 A \\
1 \mathrm{~cm} \times E D 82 / 1040 A \\
2 \mathrm{~cm} \times E D 82 / 1040 A \\
3 \mathrm{~cm} \times E D 82 / 1040 A\end{array}$ & $\begin{array}{l}41.0 \\
69.1 \\
42.0 \\
26.6\end{array}$ & $\begin{array}{l}7.6 \\
10.0 \\
11.9 \\
7.9\end{array}$ & $\begin{array}{l}7.7 \\
8.2 \\
8.1 \\
6.3\end{array}$ & $\begin{array}{l}19.1 \\
31.5 \\
21.9 \\
12.7\end{array}$ \\
\hline LSD $(P=0.05)$ & 6.09 & 1.94 & 9.78 & 4.56 \\
\hline
\end{tabular}

Table 4: Mean values of total fresh weight $\left(\mathrm{g} \mathrm{plant}^{-1}\right)$, shoot and root development indices $\left(\mathrm{g} \mathrm{g}^{-1}\right)$ of $^{\text {A. cruentus at }}$ varying depths of sowing.

\begin{tabular}{|c|c|c|c|}
\hline Treatment & $\begin{array}{l}\text { Total fresh wt. (g plant } \\
\text { 1) }\end{array}$ & Shoot dev. Index $\left(\mathrm{gg}^{-1}\right)$ & Root dev. Index $\left(\mathrm{gg}^{-1}\right)$ \\
\hline $\begin{array}{l}\mathrm{NHA}_{c} 3 \\
\text { ED82/1040A } \\
\text { LSD }(P=0.05)\end{array}$ & $\begin{array}{l}1.09 \\
1.15 \\
0.16 \\
\end{array}$ & $\begin{array}{l}2.01 \\
1.89 \\
0.30 \\
\end{array}$ & $\begin{array}{l}0.28 \\
0.15 \\
0.012 \\
\end{array}$ \\
\hline $\begin{array}{l}\text { Depth } \\
0 \mathrm{~cm} \\
1 \mathrm{~cm} \\
2 \mathrm{~cm} \\
3 \mathrm{~cm} \\
\text { LSD }(P=0.05) \\
\end{array}$ & $\begin{array}{l}0.91 \\
1.74 \\
1.15 \\
0.68 \\
0.11 \\
\end{array}$ & $\begin{array}{l}1.19 \\
3.07 \\
2.16 \\
1.38 \\
0.21 \\
\end{array}$ & $\begin{array}{l}0.13 \\
0.32 \\
0.28 \\
0.12 \\
0.038 \\
\end{array}$ \\
\hline $\begin{array}{l}\text { Depth } \times \mathrm{spp} \\
0 \mathrm{~cm} \times \mathrm{NHA}_{\mathrm{c}} 3 \\
1 \mathrm{~cm} \times \mathrm{NHA}_{\mathrm{c}} 3 \\
2 \mathrm{~cm} \times \mathrm{NHA}_{\mathrm{c}} 3 \\
3 \mathrm{~cm} \times \mathrm{NHA}_{\mathrm{c}} 3\end{array}$ & $\begin{array}{l}0.98 \\
1.43 \\
1.26 \\
0.71\end{array}$ & $\begin{array}{l}1.57 \\
2.75 \\
2.05 \\
1.67\end{array}$ & $\begin{array}{l}0.18 \\
0.43 \\
0.35 \\
0.14\end{array}$ \\
\hline $\begin{array}{l}0 \mathrm{~cm} \times E D 82 / 1040 A \\
1 \mathrm{~cm} \times \text { ED82/1040A } \\
2 \mathrm{~cm} \times \text { ED82/1040A } \\
3 \mathrm{~cm} \times \text { ED82/1040A } \\
\text { LSD }(\mathrm{P}=0.05)\end{array}$ & $\begin{array}{l}0.84 \\
2.06 \\
1.04 \\
0.65 \\
0.15\end{array}$ & $\begin{array}{l}0.82 \\
3.39 \\
2.27 \\
1.09 \\
0.29\end{array}$ & $\begin{array}{l}0.09 \\
0.020 \\
0.21 \\
0.10 \\
0.053\end{array}$ \\
\hline
\end{tabular}

Celosia argentea: The percent seedling emergence was higher in local green than in TLV8 of $C$. argentea. Seedling emergence was significantly different among the various sowing depths in the order $1 \mathrm{~cm}, 0 \mathrm{~cm}>2 \mathrm{~cm}>3 \mathrm{~cm}$. Local green sown at
$1 \mathrm{~cm}$ depth gave significantly higher percent emergence than the other variety $x$ sowing depth interactions (Table 5). Seedlings were taller at $1 \mathrm{~cm}$ that at $3 \mathrm{~cm}$ depth. The variety $x$ sowing depth effects were significantly higher for TLV8 at $1 \mathrm{~cm}$ that at $3 \mathrm{~cm}$ 
depth. The variety $x$ sowing depth effects were at $2 \mathrm{~cm}$ than all the other interactive effects (Table 5). significantly higher for TLV8 at $1 \mathrm{~cm}$ and local green

Table 5: The mean values of the vegetative characters of $C$. argentea at varying depths of sowing

\begin{tabular}{|c|c|c|c|c|}
\hline Treatment & Emergence (\%) & $\begin{array}{l}\text { Stem } \\
\text { plant }^{-1}\end{array}$ & $\begin{array}{l}\text { Leaf number } \mathrm{cm}^{2} \\
\text { plant }^{-1}\end{array}$ & $\begin{array}{l}\text { Leaf } \\
\text { plant }^{-1}\end{array}$ area $\quad \mathbf{c m}^{2}$ \\
\hline TLV8 & 51.1 & 7.2 & 7.4 & 38.82 \\
\hline Local green & 58.7 & 7.0 & 8.3 & 20.67 \\
\hline $\operatorname{LSD}(P=0.05)$ & 2.95 & 0.54 & 0.67 & 4.25 \\
\hline Depth & & & & \\
\hline $0 \mathrm{~cm}$ & 63.5 & 7.0 & 8.3 & 30.16 \\
\hline $1 \mathrm{~cm}$ & 66.9 & 8.2 & 7.9 & 42.46 \\
\hline $2 \mathrm{~cm}$ & 52.4 & 6.9 & 7.7 & 27.29 \\
\hline $3 \mathrm{~cm}$ & 36.9 & 6.3 & 7.6 & 19.09 \\
\hline $\begin{array}{l}\text { LSD }(P=0.05) \\
\text { Depth } x \text { spp }\end{array}$ & 4.32 & 0.95 & 0.91 & 5.85 \\
\hline 0cm x TLV8 & 63.9 & 7.7 & 7.0 & 37.24 \\
\hline $1 \mathrm{~cm} \times$ TLV8 & 63.5 & 9.7 & 8.0 & 60.36 \\
\hline $2 \mathrm{~cm} \times$ TLV8 & 42.1 & 4.9 & 7.0 & 27.23 \\
\hline $3 \mathrm{~cm} \times$ TLV8 & 35.0 & 6.6 & 7.9 & 23.08 \\
\hline Ocm x Local green & 63.1 & 6.3 & 9.7 & 24.56 \\
\hline $1 \mathrm{~cm} \times$ Local green & 70.3 & 6.6 & 7.8 & 24.10 \\
\hline $2 \mathrm{~cm} \times$ Local green & 62.6 & 9.1 & 8.5 & 10.95 \\
\hline $3 \mathrm{~cm} \times$ Local green & 38.9 & 6.0 & 7.3 & 8.27 \\
\hline LSD (P.=0.05) & 6.11 & 1.34 & 1.29 & 10.63 \\
\hline
\end{tabular}

Table 6: Mean values of total plant fresh wt, shoot and root development indices of $C$. argentea at varying sowing depths

\begin{tabular}{|c|c|c|c|}
\hline Treatment & Total fresh wt. (g plant $^{-1}$ ) & Shoot dev. Index $\left(\mathrm{gg}^{-1}\right)$ & Root dev. Index $\left(\mathrm{gg}^{-1}\right)$ \\
\hline TLV8 & 1.52 & 4.51 & 0.28 \\
\hline Local green & 1.23 & 4.23 & 0.18 \\
\hline $\operatorname{LSD}(P=0.05)$ & 0.16 & 0.41 & 0.03 \\
\hline Depth & & & \\
\hline $0 \mathrm{~cm}$ & 1.26 & 5.88 & 0.31 \\
\hline $1 \mathrm{~cm}$ & 2.01 & 5.87 & 0.30 \\
\hline $2 \mathrm{~cm}$ & 1.21 & 3.68 & 0.20 \\
\hline $3 \mathrm{~cm}$ & 1.02 & 2.05 & 0.16 \\
\hline $\operatorname{LSD}(P=0.05)$ & 0.18 & 0.57 & 0.03 \\
\hline Depth $\times$ Variety & & & \\
\hline 0cm x TLV8 & 1.25 & 6.73 & 0.34 \\
\hline $1 \mathrm{~cm} \times$ TLV8 & 2.40 & 6.63 & 0.39 \\
\hline $2 \mathrm{~cm} \times$ TLV8 & 1.21 & 3.32 & 0.18 \\
\hline 3cm x TLV8 & 1.24 & 1.36 & 0.20 \\
\hline $0 \mathrm{~cm} \times$ Local green & 1.26 & 5.04 & 0.27 \\
\hline $1 \mathrm{~cm} \times$ Local green & 1.62 & 5.11 & 0.21 \\
\hline $2 \mathrm{~cm} \times$ Local green & 1.21 & 4.03 & 0.12 \\
\hline $3 \mathrm{~cm} \times$ Local green & 0.80 & 2.75 & 0.10 \\
\hline LSD $(P=0.05)$ & 0.25 & 0.81 & 0.04 \\
\hline
\end{tabular}

Local green at $0 \mathrm{~cm}$ produced the higher number of leaves than other combinations. TLV8 had large leaf area than local green at 4 weeks after sowing. Sowing depth variation for leaf area was significantly in the order $1 \mathrm{~cm}>0 \mathrm{~cm}, 2 \mathrm{~cm} .3 \mathrm{~cm}$ TLV8 produced larger leaf area and total fresh vegetable at $1 \mathrm{~cm}$ depth than any other combination.

The shoot and root development indices were similar in the two varieties. They were significantly higher at $0 \mathrm{~cm}$ and $1 \mathrm{~cm}$ depths than at 2 and $3 \mathrm{~cm}$ depths. The root development index was significantly in the order $0 \mathrm{~cm}>1 \mathrm{~cm} 2 \mathrm{~cm}>3 \mathrm{~cm}$. 


\section{DISCUSSION}

In this study, both the depth of sowing and varieties influenced emergence and seedling growth in Amaranthus and Celosia. Although the main treatment effects indicated that the depth of sowing was more significant than varietal effect in Amaranthus, the varietal effect was also significant in Celosia. This indicates that the choice of variety could be based on the flowering period since a late flowering variety is usually more vegetative than the early flowering type.

A highly significant effect of sowing depth on the total plant fresh weight, root and shoot development indices in Amaranthus and Celosia were detected. In Amaranthus, the effect of sowing depth was more significant on the total plant fresh weight and shoot development index than the variety effect. This is an indication that sowing any of the two varieties of Amaranthus at an appropriate depth would ensure optimal root and shoot development as well as fresh vegetable yield. Celosia was ultimately better than Amaranthus in terms of growth even though at plant establishment, Amaranthus grew taller than Celosia.

In each crop, seedling emergence was higher in the early varieties compared to the late ones. Shallow sowing $(0$ and $1 \mathrm{~cm})$ of the varieties gave better development of plant characters than deeper sowing (2 and $3 \mathrm{~cm}$ ). The progressive decrease in the number of emerged seedlings as sowing depth increased was similar in the tested varieties of both crops. This indicates that the small seeds of Amaranthus and Celosia have food reserve for the energy required for germination and emergence which is usually sustained through the processes of oxidation during respiration.

For emergence, the root-let (radicle) and hypocotyl have to develop a pressure to pierce the soil. As the distance the hypocotyls has to traverse in the soil to the surface increases, the pressure that must be developed and utilized to pierce the soil also increases, while the inherent seed energy decreases. Hence, the greater the depth of soil to be traversed, the lower the residual energy for emergence and the lower the eventual seedling vigour. Onwueme and Adegoroye (1975) reported a significant interaction of sowing depth and heat stress on germination of Amaranthus seeds. They showed that the delay in emergence due to heat stress tended to be greater with increasing depth of sowing. Webb et al (1987) on the other hand reported that sowing Amaranthus deeper than $13 \mathrm{~cm}$ delayed and decreased emergence and that soil crusting or lack of moisture could adversely affect seedling emergence with increased sowing depth.

Amaranthus seeds broadcast on the surface $(0 \mathrm{~cm}$ sowing) had lower emergence than those sown at $1 \mathrm{~cm}$ depth. The shoot and root development indices of Amaranthus seeds sown at $0 \mathrm{~cm}$ was $40 \%$ of those at $1 \mathrm{~cm}$ depth. The low and poor root and shoot development of surface sown Amaranthus could be due to the fact that such seeds were directly exposed to the high surface temperature and possible dessication. Broadcasting also tends to put the seeds in the hottest and perhaps the driest layer of the soil so that extra energy is required by the radicle to penetrate the soil to effect establishment.

Variety TLV8 performed better than the local green in Celosia while both varieties of Amaranthus gave similar responses. This study demonstrated a significant interaction of sowing depth and variety such that the varieties (irrespective of the species) performed best at $1 \mathrm{~cm}$ depth, whereas, delayed and low percent seedling emergence occurred at $3 \mathrm{~cm}$ depth of sowing. This is similar to the findings of Odeleye, et al, 2007 that the emergence and seedling vigor of okra were significantly reduced at sowing depths of 4 and $5 \mathrm{~cm}$ leading to ultimate reduction of the yield of plants obtained from seeds sown at these depths.

\section{REFERENCES}

Abredit, D.G. 1989. No - till crop establishment on red earth soils at Katherine, Northern Territory. Effect of sowing depth and farming wheel pressure on the establishment of cowpea mug bean, soybean and maize. 29: 397 - 402.

Allessi, J. and Power, J.F. 1971. Corn emergence in relation to soil temperature and seedling depth. Agronomy Journal 63: 717 - 718

Awe, G.O. and Abegunrin, T.P. (2009). Effects of low input tillage and amaranth intercropping system on growth and yield of maize. African Journal of Agricultural Research 4 (7): 578-583

Fehr, W. R., Burris, J.S. and Gilman, D.F. 1973. Soybean emergence under field conditions. Agron. J. 65: $740-$ 742.

Gupta, S.C., Schneider, E.C. and Swan, J.B. 1989. Planting depth and tillage interactions on corn emergence. Soil Sci. Soc. Am. J. 52: $1122-1127$.

Jacobsohn, R. and Globerson, D. (1980). Decuscarota (carrot) seed wuality: I, Effects of seed size on germination, emergence and plant growth under subtropical conditions and II The importance of the 
primary umbel in carror seed production. In: Seed production Ed. P.D. Hebblethin Waite). Butterworths, London, Boston.

Lovisolo, O. and Lisa, V. 1979. Studies on Amaranthus leaf Mottle virus in the Mediterranean region. Phytopathologia Mediterranea 18: 89-93

Mayer, A.M. and Polja Koff-Mayber, A. (1975). The germination of seeds $2^{\text {nd }}$ Edition. Printed by Pargamon Press, Oxford, Vol. 5: 192pp.

Mueneke,C.O. and Ndukwe, O.O. (2008). Effect of population and spatial arrangement on the productivity of Okra/Amaranthus intercropping system. AgroScience 7 (1): 15-21

Odeleye, F.O., Odeleye O.M.O., Olaleye and Yakubu, F.B. 2007. Effect of sowing depth on emergence, growth and yield of okra (Amaranthus esculentus (L.) moench. Journal of Food, Agriculture \& Environment Vol 5 (1). 205-209.

Ogunyemi, Sola, Awodoyin, R.O., Osunkoya, O.O. Olubode, O.S. and Wewe, O.F. 2001. Response of
Vigna unguiculata (L.) Walp and Amaranthus cruentus (L.) Thell to interference from Acalypha segetalis Mull Arg on marginal lands in Southwestern Nigeria. African Crop Science Proceedings 5: 203-208

Siddiqui, M.A and Allam, M.M. (1989).Reactions of Amaranthus spp to the reniform nematode. Tests of Agrochemicals and cultivars (10): 130-131

Tayo, T.O. 1983. Growth, Development and Yield of Pigeon Pea in the Lowland Tropics. 5. Effect of sowing depth. J. Agric. Sci. (Camb.) 101: 435 - 440.

Webb, D.M., Smith, C.W. and Schulz-Schaeffer, J. (1987). Amaranth seedling emergence as affected by seeding depth and temperature on a thermogradient scale. Agron. J. 79: 23-26

Zobolo, A.M., Nkabela, C.N. and Mtetwa, D.K. (2008). Enhancing the status of Indigenous vegetables through the use of Kraal Manure substitutes and Intercropping. African Journal of Indigenous Knowledge Systems 7 (2): 211-222 